\title{
JUKSTAPOSISI BADAN PEMERIKSA KEUANGAN DAN PEMERIKSAAN DENGAN TUJUAN TERTENTU
}

\section{JUXTAPOSE ON THE SUPREME AUDIT BOARD AND THE SPECIAL PURPOSE AUDIT}

\author{
A.P. Edi Atmaja \\ Badan Pemeriksa Keuangan RI \\ Jalan Jenderal Gatot Subroto Nomor 31, Jakarta Pusat 10210 \\ ahmad.atmaja@bpk.go.id
}

\begin{abstract}
Abstrak
Tulisan ini berupaya untuk membedah permohonan uji materi atas tugas Badan Pemeriksa Keuangan dalam melaksanakan pemeriksaan dengan tujuan tertentu. Tulisan ini hendak menganalisis dua permasalahan. Pertama adalah mengenai dalil-dalil para pemohon yang tertuang dalam alasan permohonan (posita) dan kedua ialah kedudukan hukum (legal standing) para pemohon. Kesimpulan tulisan ini menunjukkan bahwa, pertama, para pemohon tidak memahami-bahkan keliru secara fatal dalam memahami-pemeriksaan dengan tujuan tertentu yang dilaksanakan oleh Badan Pemeriksa Keuangan sehingga permohonan menjadi tidak jelas atau kabur (obscuur libel). Kedua, para pemohon tidak memiliki kedudukan hukum. Tulisan ini merekomendasikan kepada Mahkamah Konstitusi untuk memutuskan bahwa permohonan para pemohon tidak dapat diterima (niet ontvankelijk verklaard).
\end{abstract}

Kata Kunci: Badan Pemeriksa Keuangan, Pemeriksaan dengan Tujuan Tertentu, Kedudukan Hukum Pemohon

\begin{abstract}
This paper seeks to discuss the judicial review of the Supreme Audit Board's duty to implement special purpose audit. This paper wants to analyze two problems. First is regarding the arguments of the petitioners contained in the reasons for the petition (posita) and second is the legal standing of the petitioners. The conclusion of this paper shows that, first, the petitioners did not understand-even fatally mistakenly understood-the special purpose audit carried out by the Supreme Audit Board so their requests became unclear or obscure (obscuur libel). Second, the petitioners do not have a legal standing. This paper recommends the Constitutional Court to decide that the petition of the petitioners cannot be accepted (niet ontvankelijk verklaard).
\end{abstract}

Keywords: The Supreme Audit Board, Special Purpose Audit, Legal Standing

\section{PENDAHULUAN}

Pada 29 Agustus 2019 pukul 13.54 WIB, dua dosen dan satu mahasiswa mengajukan permohonan uji materi ke Mahkamah Konstitusi (selanjutnya disebut MK) atas UndangUndang Nomor 15 Tahun 2004 tentang Pemeriksaan Pengelolaan dan Tanggung Jawab Keuangan Negara (selanjutnya disebut UU 15/2004) dan Undang-Undang Nomor 15 Tahun 2006 tentang Badan Pemeriksa Keuangan (selanjutnya disebut UU 15/2006) terhadap UndangUndang Dasar Negara Republik Indonesia Tahun 1945 (selanjutnya disebut UUD 1945). 
Permohonan tercatat dengan tanda terima nomor 1900/PAN.MK/VIII/2019 ${ }^{1}$ dan teregistrasi sebagai Perkara Nomor 54/PUU-XVII/2019 pada 17 September 2019 pukul 10.00 WIB. ${ }^{2}$

Materi yang hendak diuji dalam permohonan tersebut ialah frasa "pemeriksaan dengan tujuan tertentu" dalam Pasal 4 ayat (1) UU 15/2004 yang selengkapnya menyatakan, "Pemeriksaan sebagaimana dimaksud dalam Pasal 2 terdiri atas pemeriksaan keuangan, pemeriksaan kinerja, dan pemeriksaan dengan tujuan tertentu," dan Pasal 6 ayat (3) UU 15/2006 yang selengkapnya menyatakan, "Pemeriksaan BPK mencakup pemeriksaan keuangan, pemeriksaan kinerja, dan pemeriksaan dengan tujuan tertentu."

Penjelasan Pasal 4 ayat (1) UU 15/2004 menerangkan bahwa pemeriksaan dengan tujuan tertentu meliputi antara lain pemeriksaan atas hal-hal lain di bidang keuangan, pemeriksaan investigatif, dan pemeriksaan atas sistem pengendalian intern pemerintah. Menurut para pemohon, tugas Badan Pemeriksa Keuangan (selanjutnya disebut BPK) untuk melaksanakan pemeriksaan dengan tujuan tertentu bertentangan dengan Pasal 1 ayat (3), ${ }^{3}$ Pasal 28D ayat (1), 4 dan Pasal 23E ayat (1)5 UUD 1945.

Permohonan uji materi ini tampak menarik karena diajukan sekira lima belas tahun pascaberlakunya UU 15/2004 dan tiga belas tahun pasca-berlakunya UU 15/2006. Di samping itu, permohonan ini diajukan setelah pelaksanaan sekian banyak pemeriksaan dengan tujuan tertentu oleh BPK. Jika permohonan dikabulkan oleh MK, lantas bagaimanakah status hukum dari sekian banyak laporan hasil pemeriksaan dengan tujuan tertentu itu, yang memuat sekian triliun rupiah kerugian negara yang mesti dipulihkan?

Dalam tahun 2018 saja, misalnya, BPK telah menerbitkan 286 laporan hasil pemeriksaan dengan tujuan tertentu, yakni 36 laporan pada semester I $^{6}$ dan 250 laporan pada semester II. ${ }^{7}$ Jumlah tersebut belum termasuk 16 laporan hasil pemeriksaan investigatif dan 4.994 laporan hasil pemeriksaan atas pertanggungjawaban penerimaan dan pengeluaran dana bantuan keuangan partai politik dari anggaran pendapatan dan belanja daerah ${ }^{8}$ yang termasuk dalam rumpun pemeriksaan dengan tujuan tertentu.

Tulisan ini hendak menimbang kemungkinan-kemungkinan pertimbangan hukum MK atas permohonan uji materi tugas BPK untuk melaksanakan pemeriksaan dengan tujuan tertentu. Tulisan ini dapat pula dianggap sebagai "eksaminasi" atas permohonan uji materi tersebut seperti halnya suatu eksaminasi atas proses peradilan. ${ }^{9}$

\footnotetext{
${ }^{1}$ Viktor Santoso Tandiasa dkk., "Berkas Permohonan Nomor 1900/PAN.MK/VIII/2019", https://mkri.id/public/filesimpp/berkas 2683 1900\%20-\%20Dr.\%20Ahmad\%20Redi,\%20S.H.,\%20M.H.,\%20dkk.pdf, diunduh 8 September 2019.

${ }^{2}$ Mahkamah Konstitusi RI, "Registrasi”, https://mkri.id/index.php?page=web.Registrasi2\&menu=4, diunduh 19 September 2019.

${ }^{3}$ Pasal 1 ayat (3) UUD 1945 menyatakan, "Negara Indonesia adalah negara hukum."

${ }^{4}$ Pasal 28D ayat (1) UUD 1945 menyatakan, "Setiap orang berhak atas pengakuan, jaminan, perlindungan, dan kepastian hukum yang adil serta perlakuan yang sama di hadapan hukum."

${ }^{5}$ Pasal 23E ayat (1) UUD 1945 menyatakan, "Untuk memeriksa pengelolaan dan tanggung jawab tentang keuangan negara diadakan satu Badan Pemeriksa Keuangan yang bebas dan mandiri."

${ }^{6}$ Badan Pemeriksa Keuangan RI, Ikhtisar Hasil Pemeriksaan Semester I Tahun 2018, https://www.bpk.go.id/assets/files/ihps/2018///ihps i 2018 1538459607.pdf, diunduh 8 September 2019, h. xxvi.

${ }^{7}$ Badan Pemeriksa Keuangan RI, Ikhtisar Hasil Pemeriksaan Semester II Tahun 2018, https://www.bpk.go.id/assets/files/ihps/2018/ll/ihps ii 2018 1559017101.pdf, diunduh 8 September 2019, h. xxx.

${ }^{8}$ Disarikan dari Ikhtisar Hasil Pemeriksaan Semester I Tahun 2018 dan Ikhtisar Hasil Pemeriksaan Semester II Tahun 2018.

${ }^{9}$ Peradilan konstitusi memiliki sejumlah perbedaan dengan peradilan pidana, perdata, atau tata usaha negara, misalnya dalam hal para pihak yang terlibat dalam proses persidangan. Selain hakim, para pihak dalam peradilan konstitusi-dalam hal ini pengujian undang-undang terhadap undang-undang dasar-terdiri atas pemohon, pembentuk undang-undang, lembaga negara yang terkait dengan permohonan, dan/atau pihak terkait yang berkepentingan secara tidak langsung dengan permohonan. Oleh sebab itu, setiap produk yang dihasilkan dalam pengujian undang-undang terhadap undang-undang dasar, yakni putusan, permohonan tertulis dari pemohon, keterangan dan/atau risalah rapat dari pembentuk undang-undang, keterangan tertulis dari lembaga negara
} 
Bagian pertama tulisan ini ingin mendedahkan suatu pengantar singkat mengenai kedudukan hukum (legal standing) pemohon. Konsep mengenai kedudukan hukum pemohon penting untuk dibahas karena ia merupakan unsur esensial dalam proses peradilan konstitusi. Seorang pemohon harus dapat meyakinkan hakim bahwa ia benar-benar merupakan pihak yang memiliki kedudukan hukum-dan hal itu sejatinya telah tampak semenjak pengajuan berkas permohonan.

Bagian selanjutnya akan mengulas secara ringkas mengenai BPK, tugas, dan wewenangnya. Bagian ini berikhtiar untuk menghubungkan kedudukan konstitusional BPK dengan tugas dan wewenang yang diperolehnya akibat kedudukan konstitusionalnya itu secara historis. Dengan demikian, salah satu tugas BPK, yakni pemeriksaan dengan tujuan tertentu, dapat memperoleh lanskap historis dan konstitusionalnya.

Kemudian, bagian terakhir dari tulisan ini akan mengelaborasi sejumlah kekeliruan para pemohon dalam memahami tugas BPK untuk melaksanakan pemeriksaan dengan tujuan tertentu sebagaimana tersurat dalam alasan-alasan permohonan (posita). Selanjutnya juga akan dielaborasi mengenai sejauh mana kedudukan hukum para pemohon dan apakah permohonannya layak atau tidak layak dipertimbangkan lebih lanjut oleh MK.

\section{PEMBAHASAN}

\section{Kedudukan Hukum Pemohon: Suatu Pengantar}

Pasal 51 ayat (1) Undang-Undang Nomor 24 Tahun 2003 tentang MK sebagaimana telah diubah dengan Undang-Undang Nomor 8 Tahun 2011 (selanjutnya disebut UU 24/2003) menyatakan bahwa pemohon dianggap memiliki kedudukan hukum (legal standing) bilamana ia merupakan pihak yang hak dan/atau kewenangan konstitusionalnya dirugikan oleh berlakunya undangundang yang dimohonkan pengujian yang, secara limitatif, terdiri atas empat klasifikasi.

Pertama, perorangan warga negara Indonesia. ${ }^{10}$ Kedua, kesatuan masyarakat hukum adat sepanjang masih hidup dan sesuai dengan perkembangan masyarakat dan prinsip Negara Kesatuan Republik Indonesia yang diatur dalam undang-undang. Ketiga, badan hukum publik atau privat. Keempat, lembaga negara.

Terkait batasan-batasan kerugian hak dan/atau kewenangan konstitusional tersebut, sejak Putusan Nomor 006/PUU-III/2005, Putusan Nomor 11/PUU-V/2007, dan putusan-putusan seterusnya, MK berpendirian bahwa kerugian hak dan/atau kewenangan konstitusional sebagaimana dimaksud Pasal 51 ayat (1) UU 24/2003 harus memenuhi lima syarat yang merupakan satu rangkaian, satu kesatuan, dan tidak dapat dipisahkan.

Pertama, adanya hak dan/atau kewenangan konstitusional pemohon yang diberikan oleh UUD 1945. Kedua, hak dan/atau kewenangan konstitusional tersebut oleh pemohon dianggap

yang terkait dengan permohonan, dan keterangan tambahan (ad informandum) dari pihak terkait yang berkepentingan secara tidak langsung dengan permohonan dapat dan layak untuk dieksaminasi. Eksaminasi dilakukan untuk melihat sejauh mana pertimbangan hukum-yang didalilkan oleh para pihak: sudah sesuai ataukah bertentangan dengan prinsip-prinsip hukum dan keadilan, legal justice, moral justice, dan juga social justice. Lihat Emerson Yuntho dkk., Panduan Eksaminasi Publik (Edisi Revisi 2011), Jakarta: Indonesia Corruption Watch, 2011, h. 29.

${ }^{10}$ Khusus mengenai "perorangan warga negara Indonesia" MK, melalui Peraturan MK Nomor 06/PMK/2005 tentang Pedoman Beracara dalam Perkara Pengujian Undang-Undang, memperluas definisi klasifikasi pihak termasuk juga kelompok orang yang mempunyai kepentingan yang sama. Ahmad Fadlil Sumadi, "Hukum Acara Mahkamah Konstitusi dalam Teori dan Praktik", Jurnal Konstitusi, Volume 8, Nomor 6, Desember 2011, h. 863. 
dirugikan oleh berlakunya undang-undang yang dimohonkan pengujian. Ketiga, kerugian hak dan/atau kewenangan konstitusional tersebut harus bersifat spesifik dan aktual atau setidaktidaknya potensial yang menurut penalaran yang wajar dapat dipastikan akan terjadi.

Keempat, adanya hubungan sebab-akibat (causal verband) antara kerugian dimaksud dengan berlakunya undang-undang yang dimohonkan pengujian. Kelima, adanya kemungkinan bahwa dengan dikabulkannya permohonan, maka kerugian hak dan/atau kewenangan konstitusional seperti yang didalilkan tidak akan atau tidak lagi terjadi.

Kedudukan hukum pemohon sejatinya merupakan unsur esensial dalam hukum acara (procedural law) di MK. Sebab, tidak semua orang dapat menjadi pemohon dan dapat mengajukan permohonan uji materi-dalam hal ini pengujian undang-undang terhadap undang-undang dasar. Adanya kepentingan hukum semata tidak cukup menjadi alas hak bagi seseorang untuk mengajukan permohonan. ${ }^{11}$

Di samping itu, kedudukan hukum wajib dimiliki oleh pemohon supaya persidangan perkara dapat beranjak ke proses selanjutnya, yakni pemeriksaan persidangan. Di MK dikenal empat jenis persidangan, yakni (1) pemeriksaan pendahuluan, (2) pemeriksaan persidangan, (3) rapat permusyawaratan hakim, dan (4) pengucapan putusan. Empat jenis persidangan ini dapat juga dilihat sebagai tahapan persidangan suatu perkara kendati yang belakangan ini sesungguhnya kurang tepat. Sebab, dalam perkara tertentu majelis hakim hanya memerlukan pemeriksaan pendahuluan dan, setelah dilakukan rapat permusyawaratan hakim, perkara tersebut sudah dapat diputuskan. ${ }^{12}$

Hakim memeriksa kedudukan hukum pemohon pada saat pemeriksaan pendahuluan. ${ }^{13}$ Pemohon yang tidak dapat menguraikan dengan jelas dalam permohonannya tentang hak dan/atau kewenangan konstitusionalnya yang dianggap dirugikan dengan berlakunya undangundang, sehingga dengan demikian tidak memiliki kedudukan hukum, akan menerima putusan MK yang menyatakan bahwa permohonan tersebut tidak dapat diterima (niet ontvankelijk verklaard). ${ }^{14}$

BPK telah melaksanakan pemeriksaan kinerja atas efektivitas penanganan perkara pengujian undang-undang di MK. Laporan hasil pemeriksaan antara lain memuat informasi bahwa terdapat sembilan putusan MK dengan amar putusan "tidak dapat diterima" dalam periode tahun 2016 dan triwulan III tahun 2017 yang diputus setelah pemeriksaan persidangan. ${ }^{15}$ Menurut BPK, hal tersebut mengakibatkan tidak tercapainya penyelesaian perkara yang sederhana, cepat, dan berbiaya ringan sesuai dengan asas penyelenggaraan kekuasaan kehakiman. ${ }^{16}$

BPK menyatakan lebih lanjut,

\footnotetext{
${ }^{11}$ Hukum acara perdata mempunyai adagium tentang ini, yakni point d'interet point d'action (barangsiapa mempunyai kepentingan hukum, maka ia boleh mengajukan gugatan). Lihat Sudikno Mertokusumo, "Gugatan Actio Popularis dan Batas Kewenangan Hakim", https://www.hukumonline.com/berita/baca/hol15774/gugatan-actio-popularis-dan-batas-kewenangan-hakim, diunduh 9 September 2019.

12 Tim Penyusun Hukum Acara Mahkamah Konstitusi, Hukum Acara Mahkamah Konstitusi, Jakarta: Sekretariat Jenderal dan Kepaniteraan Mahkamah Konstitusi RI, 2010, h. 45.

${ }^{13}$ Selain itu, hakim juga memeriksa kewenangan MK dalam permohonan tersebut dan pokok permohonan. Ibid., h. 125.

${ }^{14}$ Harjono, Konstitusi sebagai Rumah Bangsa, Jakarta: Sekretariat Jenderal dan Kepaniteraan Mahkamah Konstitusi RI, 2008, h. 176, dalam Ibid., h. 98.

${ }^{15}$ Badan Pemeriksa Keuangan RI, Laporan Hasil Pemeriksaan Kinerja atas Efektivitas Penanganan Perkara Pengujian UndangUndang Tahun Anggaran 2016 dan Tahun Anggaran 2017 (sampai dengan Triwulan III) pada Mahkamah Konstitusi di Jakarta, Nomor 02/HP/XVI/01/2018 Tanggal 23 Januari 2018, h. 35.

${ }^{16}$ Ibid., h. 36.
} 
“[...] jika amar putusannya adalah tidak dapat diterima dengan alasan tidak memenuhi legal standing dalam persidangan perkara pengujian undang-undang, seharusnya sudah dapat diputuskan pada saat pemeriksaan pendahuluan karena pada saat pemeriksaan pendahuluan, hakim telah melakukan pemeriksaan kelengkapan dan kejelasan materi permohonan, khususnya kedudukan hukum (legal standing) pemohon dan pokok permohonan, sehingga perkara tidak berlarut-larut sampai dengan pemeriksaan persidangan." 17

Atas kondisi tersebut, BPK menyinyalir tidak bekerjanya tugas dan fungsi peneliti sebagai salah satu penyebab. Menurut BPK, tugas dan fungsi peneliti berdasarkan uraian jabatan adalah mengkaji perkara yang teregistrasi dan hasil kajian itu dapat menjadi bahan masukan bagi hakim dalam memeriksa perkara. ${ }^{18}$ Dengan demikian, para peneliti seharusnya dapat menyediakan sekaligus memverifikasi, misalnya, data profil para pemohon untuk membantu hakim menimbang kedudukan hukum serta kerugian konstitusional pemohon sehingga perkara dapat lekas diputus dan tidak berlarut-larut.

\section{BPK, Tugas, dan Wewenangnya: Selayang Pandang}

UUD 1945 mengamanatkan diadakannya suatu badan (board) yang bebas dan mandiri dalam memeriksa pengelolaan dan pertanggungjawaban keuangan negara. Badan yang telah mengemuka sejak perumusan konstitusi negara pada 11 Juli 1945 ini kemudian dikenal sebagai BPK. ${ }^{19}$

Eksistensi BPK sejatinya adalah penolakan para pendiri bangsa akan prinsip trias politika yang memisahkan kekuasaan negara dalam tiga gugus semata: eksekutif, legislatif, dan yudikatif. Sukarno, proklamator kemerdekaan dan presiden pertama RI, menyatakan dalam rapat 11 Juli 1945 itu bahwa memisahkan kekuasaan negara berdasarkan prinsip trias politika belaka tidak akan mampu mewujudkan kesejahteraan bagi seluruh rakyat Indonesia. ${ }^{20}$

Padahal, Indonesia sebagai negara kesatuan yang berbentuk republik sedari mula diharapkan oleh para pendiri bangsa dapat mencapai cita-cita dan tujuan negara yang sedikit-banyak mengandung anasir "sosial ekonomi". Anasir "sosial ekonomi" ini mengejawantah dalam Pembukaan UUD 1945 melalui rumusan "kemerdekaan Indonesia yang adil dan makmur” serta "pembentukan pemerintahan yang bertujuan untuk memajukan kesejahteraan umum".

Dengan cita-cita dan tujuan negara semacam itu, tentu saja dibutuhkan suatu badan yang secara khusus dapat menjadi pemandu negara dalam mewujudkan tujuan dan cita-citanya dalam bidang sosial ekonomi. Maka tampillah BPK sebagai cabang lain kekuasaan negara yang mengemban fungsi auditif: pemeriksaan atas pengelolaan dan tanggung jawab keuangan negara.

\footnotetext{
${ }^{17} \mathrm{lbid}$., h. 35. Dalam laporan, BPK tidak menghitung dan menyebutkan nilai inefisiensi keuangan negara akibat penyelesaian perkara yang berlarut-larut ini jika dihubungkan dengan, misalnya, (1) jumlah realisasi anggaran untuk penyelesaian tiap-tiap perkara dan/atau (2) potensi kerugian negara akibat rekayasa permohonan dengan tujuan untuk pencapaian target penyerapan anggaran.

18 lbid.

19 Jika dirunut secara historis, sesungguhnya embrio BPK telah ada sejak era Pemerintah Hindia Belanda dalam wujud Algemeene Rekenkamer, lembaga yang didirikan oleh Gubernur Jenderal Hindia Belanda ke-36, Herman Willem Daendels (1762-1818) pada 19 Desember 1808. Harun Kamil dkk., Badan Pemeriksa Keuangan dalam Proses Perubahan Undang-Undang Dasar Negara Republik Indonesia Tahun 1945, Jakarta: Sekretariat Jenderal Badan Pemeriksa Keuangan RI, 2012, h. 15. Dengan demikian, para pendiri bangsa sebenarnya hanya melanjutkan tata negara yang telah terbentuk sejak era Pemerintah Hindia Belanda-tentu dengan pelbagai macam modifikasi.

${ }^{20}$ Ibid., h. 2.
} 
Dengan landasan konstitusional Pasal 23 ayat (5) UUD 1945 (sebelum amendemen), ${ }^{21}$ BPK baru dapat melaksanakan tugas pasca-terbitnya Penetapan Pemerintah Tahun 1946 Nomor 11/Um tentang Pembentukan BPK. Regulasi ini memungkinkan BPK dapat bekerja secara aktif mulai 1 Januari $1947 . .^{22}$

BPK mengalami perubahan nama menjadi Dewan Pengawas Keuangan dan berpindah kedudukan dari Magelang ke Bogor pada saat berlakunya Konstitusi Republik Indonesia Serikat (27 Desember 1949-17 Agustus 1950) kemudian Undang-Undang Dasar Sementara Tahun 1950 (17 Agustus 1950-5 Juli 1959). Dengan adanya Dekrit Presiden 5 Juli 1959, UUD 1945 (sebelum amendemen) diberlakukan kembali dan Dewan Pengawas Keuangan dipulihkan menjadi BPK.

Untuk menyempurnakan BPK agar dapat menjadi alat kontrol yang efektif, pada 12 Oktober 1963 pemerintah menerbitkan Peraturan Pemerintah Pengganti Undang-Undang Nomor 7 Tahun 1963 tentang BPK. ${ }^{23}$ Regulasi itu pada 2 Mei 1964 dicabut dan diganti dengan Peraturan Pemerintah Pengganti Undang-Undang Nomor 6 Tahun 1964 tentang BPK yang lalu diubah dan ditetapkan menjadi Undang-Undang Nomor 17 Tahun $1965 .{ }^{24}$

Pada rezim Orde Baru, Undang-Undang Nomor 17 Tahun 1965 dicabut dan diganti dengan Undang-Undang Nomor 5 Tahun 1973 tentang BPK. Peraturan ini berhasil bertahan tanpa perubahan dan pencabutan selama 33 tahun, bahkan masih cukup bertenaga hingga tujuh tahun pasca-lengsernya rezim Orde Baru. Akhirnya UU 15/2006 terbit sebagai amanat dari amendemen konstitusi di era Reformasi dan regulasi pelengkap dari paket undang-undang keuangan negara. ${ }^{25}$

BPK, dengan semangat Reformasi, masih mengemban tugas yang sama: memeriksa pengelolaan dan tanggung jawab keuangan negara. Namun, UU 15/2006 mengguratkan garis demarkasi antara tugas dan wewenang BPK. Pasal 6 sampai 8 UU 15/2006 mengatur tentang tugas BPK dan Pasal 9 sampai 12 mengatur soal wewenang BPK. Semangat Reformasi dan amendemen konstitusi pun memperluas tugas dan wewenang BPK itu serta objek pemeriksaan BPK melalui Undang-Undang Nomor 17 Tahun 2003 tentang Keuangan Negara.

Sesuai Pasal 2 UU 17/2003, objek pemeriksaan BPK adalah keuangan negara yang mencakup sembilan perkara. Pertama, hak negara untuk memungut pajak, mengeluarkan dan mengedarkan uang, dan melakukan pinjaman. Kedua, kewajiban negara untuk menyelenggarakan tugas layanan umum pemerintahan negara dan membayar tagihan pihak ketiga. Ketiga, penerimaan negara. Keempat, pengeluaran negara. Kelima, penerimaan daerah. Keenam, pengeluaran daerah.

Ketujuh, kekayaan negara/kekayaan daerah yang dikelola sendiri atau oleh pihak lain berupa uang, surat berharga, piutang, barang, serta hak-hak lain yang dapat dinilai dengan uang, termasuk kekayaan yang dipisahkan pada perusahaan negara/perusahaan daerah. Kedelapan,

\footnotetext{
${ }^{21}$ Pasal 23 ayat (5) UUD 1945 (sebelum amendemen) menyatakan, "Untuk memeriksa tanggung jawab tentang keuangan negara diadakan suatu Badan Pemeriksa Keuangan yang peraturannyaditetapkan dengan undang-undang. Hasil pemeriksaan itu diberitahukan kepada Dewan Perwakilan Rakyat."

${ }^{22}$ Harun Kamil dkk., op. cit., h. 8. Tanggal 1 Januari lantas ditetapkan menjadi hari lahir BPK.

${ }^{23}$ lbid., h. 10.

${ }^{24}$ Sebenarnya menarik apabila mengulas barang sepeminuman kopi mengenai perbedaan struktur kelembagaan BPK dan Dewan Pengawas Keuangan sesuai periode, dasar yuridis, dan atmosfer politik yang melingkupinya. Namun, alangkah menyenangkan jika tulisan ini tidak membahas sampai ke situ.

${ }^{25}$ Paket undang-undang keuangan negara terdiri atas Undang-Undang Nomor 17 Tahun 2003 tentang Keuangan Negara, UndangUndang Nomor 1 Tahun 2004 tentang Perbendaharaan Negara, dan UU 15/2004.
} 
kekayaan pihak lain yang dikuasai oleh pemerintah dalam rangka penyelenggaraan tugas pemerintahan dan/atau kepentingan umum. Kesembilan, kekayaan pihak lain yang diperoleh dengan menggunakan fasilitas yang diberikan pemerintah.

Sementara itu, pihak-pihak yang diperiksa BPK ialah para pemegang kekuasaan pengelolaan keuangan negara itu, yang meliputi pemerintah pusat, pemerintah daerah, lembaga negara selain pemerintah pusat dan pemerintah daerah, Bank Indonesia, badan usaha milik negara, badan layanan umum, badan usaha milik daerah, dan lembaga atau badan lain yang mengelola keuangan negara. ${ }^{26}$

Pasal 6 ayat (3) UU 15/2006 menjabarkan lebih lanjut tugas BPK "memeriksa pengelolaan dan tanggung jawab keuangan negara” dalam wujud pemeriksaan keuangan, pemeriksaan kinerja, dan pemeriksaan dengan tujuan tertentu. Definisi dan deskripsi lebih lanjut tentang penjabaran tugas BPK itu terdapat dalam Pasal 4 UU 15/2004 dan penjelasannya yang menyatakan bahwa, pertama, pemeriksaan keuangan adalah pemeriksaan atas laporan keuangan. ${ }^{27}$

Kedua, pemeriksaan kinerja adalah pemeriksaan atas pengelolaan keuangan negara yang terdiri atas pemeriksaan aspek ekonomi dan efisiensi serta pemeriksaan aspek efektivitas. ${ }^{28}$ Ketiga, pemeriksaan dengan tujuan tertentu adalah pemeriksaan yang tidak termasuk dalam pemeriksaan keuangan dan pemeriksaan kinerja, ${ }^{29}$ yang meliputi antara lain (cetak miring dari penulis) ${ }^{30}$ pemeriksaan atas hal-hal lain di bidang keuangan, pemeriksaan investigatif, dan pemeriksaan atas sistem pengendalian intern pemerintah. ${ }^{31}$

\section{Permohonan Pemohon: Dua Kritik}

\section{Pemeriksaan dengan tujuan tertentu, kesalahpahaman, dan kekeliruan fatal para pemohon}

Dalam Berkas Permohonan Nomor 1900/PAN.MK/VIII/2019 perihal Permohonan Pengujian Pasal 4 ayat (1) UU 15/2004 dan Pasal 6 ayat (3) UU 15/2006 terhadap UUD 1945, para pemohon mendalilkan tiga alasan permohonan (posita). ${ }^{32}$

Pertama, BPK adalah lembaga negara yang diberikan kewenangan (cetak miring dari penulis) secara konstitusional untuk memeriksa pengelolaan dan tanggung jawab keuangan negara. 33 Kata bercetak miring tersebut menunjukkan bahwa para pemohon tidak bisa membedakan antara "tugas" dan "wewenang” sebab memeriksa pengelolaan dan tanggung jawab keuangan negara adalah tugas, bukan wewenang, BPK.

Menurut Kamus Besar Bahasa Indonesia, tugas adalah (sesuatu) yang wajib dikerjakan atau yang ditentukan untuk dilakukan; pekerjaan yang menjadi tanggung jawab seseorang;

\footnotetext{
${ }^{26}$ Pasal 6 ayat (1) UU 15/2006.

27 Pasal 4 ayat (2) UU 15/2004.

${ }^{28}$ Pasal 4 ayat (3) UU $15 / 2004$.

29 Pasal 4 ayat (4) UU 15/2004.

${ }^{30}$ Frasa tercetak miring ini menunjukkan kearifan pembentuk undang-undang dalam membuka kemungkinan jenis pemeriksaan dengan tujuan tertentu yang tidak terbatas pada tiga hal tersebut mengikuti perkembangan ilmu pemeriksaan (auditing)

31 Penjelasan Pasal 4 ayat (4) UU 15/2004.

32 Pada 7 Oktober 2019, para pemohon mengajukan perbaikan permohonan. Perbaikan pemohonan ini menarik sebab, di samping terdapat perbaikan substansi permohonan, juga terdapat penggantian (substitusi) pemohon. Dalam permohonan pengujian undangundang, hal ini amat jarang terjadi. Viktor Santoso Tandiasa dkk., "Perbaikan Berkas Permohonan Nomor 1900/PAN.MK/VIII/2019", https://mkri.id/public/filesimpp/berkasReg 2769 Perbaikan\%20Permohonan\%20Perkara\%20Nomor\%2054\%20PUU\%20XVII\%202 019.pdf, diunduh 19 Februari 2020.

${ }^{33}$ Ibid., h. 18.
} 
pekerjaan yang dibebankan; suruhan (perintah) untuk melakukan sesuatu; fungsi yang harus dikerjakan. ${ }^{34}$ Sementara wewenang adalah hak dan kekuasaan untuk bertindak; kewenangan; kekuasaan membuat keputusan, memerintah, dan melimpahkan tanggung jawab kepada orang lain; fungsi yang boleh tidak dilaksanakan. 35

Kegagalan para pemohon membedakan antara "tugas" dan "wewenang” BPK ini mengakibatkan permohonan cacat substantif. Pasal 6 ayat (3) UU 15/2006 yang menyatakan bahwa pemeriksaan BPK mencakup pemeriksaan keuangan, pemeriksaan kinerja, dan pemeriksaan dengan tujuan tertentu terletak dalam bagian pasal-pasal yang mengatur tentang tugas BPK. Dengan demikian, pemeriksaan dengan tujuan tertentu yang dipersoalkan para pemohon adalah bagian dari tugas BPK memeriksa pengelolaan dan tanggung jawab keuangan negara, sehingga tidak dapat diuji konstitusionalitasnya sebab hal itu sama saja dengan menguji materi UUD 1945 .

Kedua, pemeriksaan dengan tujuan tertentu, menurut para pemohon, menimbulkan persoalan dan isu konstitusionalitas karena tidak memiliki kejelasan atas makna "tujuan tertentu" sehingga menimbulkan ketidakpastian hukum serta melanggar prinsip pembentukan peraturan perundang-undangan. ${ }^{36}$

Para pemohon berpendapat bahwa basis kewenangan konstitusional BPK adalah pemeriksaan atas pengelolaan dan tanggung jawab keuangan negara yang, apabila dimaknai secara tekstualgramatikal, hanyalah terdiri atas pemeriksaan keuangan dan pemeriksaan kinerja. ${ }^{37}$ Sehingga apabila ada kewenangan lain di luar kedua kedua kewenangan konstitusional tersebut, maka sejatinya kewenangan itu adalah inkonstitusional, karena telah memperluas kewenangan konstitusional yang telah diberikan oleh UUD 1945 secara eksplisit dan limitatif. 38

Pendapat para pemohon tersebut tidak sesuai dengan landasan keilmuan dan yuridis. Pemeriksaan dengan tujuan tertentu atau pemeriksaan khusus (special purpose audit) telah lazim dikenal dalam ilmu akuntansi dan pemeriksaan (auditing). Menurut Sukrisno Agoes, pemeriksaan khusus adalah suatu pemeriksaan terbatas yang pada akhir pemeriksaannya pemeriksa (auditor) tidak perlu memberikan pendapat terhadap kewajaran laporan keuangan secara keseluruhan. Pendapat yang diberikan terbatas pada pos-pos atau masalah tertentu yang diperiksa saja sebab prosedur pemeriksaan yang dilakukan juga terbatas. ${ }^{39}$

Jenis-jenis pemeriksaan pun sebetulnya tidak hanya terbatas pada tiga jenis pemeriksaan yang menjadi gugus tugas BPK itu. Menurut Indra Bastian, pemeriksaan/audit pada sektor publik terdiri atas audit kepatuhan, audit keuangan program publik, audit kinerja sektor publik, dan audit investigasi. $4^{\circ 0}$ Lain lagi menurut Sukrisno Agoes dan Jan Hoesada: jenis-jenis audit dapat berupa audit keuangan atau general audit, audit khusus, dan audit teknologi informasi. ${ }^{41}$

\footnotetext{
${ }^{34}$ Badan Pengembangan dan Pembinaan Bahasa, Kementerian Pendidikan dan Kebudayaan RI, "KBBI Daring", https://kbbi.kemdikbud.go.id/entri/tugas, diunduh 4 Oktober 2019.

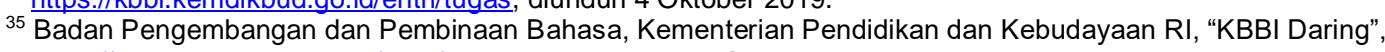
https://kbbi.kemdikbud.go.id/entri/wewenang, diunduh 4 Oktober 2019.

${ }^{36}$ Viktor Santoso Tandiasa dkk., op. cit., h. 25.

${ }^{37}$ Ibid., h. 26.

$38 \mathrm{lbid}$.

${ }^{39}$ Sukrisno Agoes, Auditing: Petunjuk Praktis Pemeriksaan Akuntan oleh Akuntan Publik (Edisi 4 Buku I), Jakarta: Salemba Empat, 2012, h. 11.

${ }^{40}$ Indra Bastian, Audit Sektor Publik: Pemeriksaan Pertanggungjawaban Pemerintahan, Jakarta: Salemba Empat, 2014 , h. 16-21.

${ }^{41}$ Sukrisno Agoes dan Jan Hoesada, Bunga Rampai Auditing (Edisi 2), Jakarta: Salemba Empat, 2012, h. 46-47.
} 
Menurut Baharuddin Aritonang, anggota BPK periode 2004-2009, rumusan Pasal 4 ayat (4) UU 15/2004 yang menyatakan bahwa pemeriksaan dengan tujuan tertentu adalah pemeriksaan yang tidak termasuk dalam pemeriksaan keuangan dan pemeriksaan kinerja menunjukkan ada perbedaan di antara ketiganya. Baharuddin Aritonang menjelaskan lebih lanjut,

"Yang membedakan bukanlah metode tapi tahap pemeriksaan. Pemeriksaan dengan tujuan tertentu dilakukan sebagai tindak lanjut pemeriksaan keuangan dan pemeriksaan kinerja, karena ada beberapa persoalan penting yang harus diselesaikan, misalnya pelaksanaan rekomendasi BPK oleh instansi terperiksa, atau karena diduga ada unsur pidana dalam tindakan keuangan atau kinerja intansi yang telah diperiksa." 42

Di samping itu, audit dengan tujuan tertentu juga merupakan praktik yang lazim dilakukan oleh aparat pengawasan intern pemerintah (APIP), seperti Badan Pengawasan Keuangan dan Pembangunan, inspektorat jenderal pada kementerian atau lembaga negara/pemerintahan, inspektorat pada pemerintah daerah provinsi, dan inspektorat pada pemerintah daerah kabupaten/kota. Landasan hukum wewenang APIP untuk melaksanakan audit dengan tujuan tertentu adalah Peraturan Pemerintah Nomor 6o Tahun 2008 tentang Sistem Pengendalian Intern Pemerintah (selanjutnya disebut PP 60/2008).

Pasal 48 ayat (2) PP 60/2008 menyatakan bahwa pengawasan intern atas penyelenggaraan tugas dan fungsi instansi pemerintah oleh APIP adalah berupa audit, reviu, evaluasi, pemantauan, dan kegiatan lainnya. Audit ini meliputi audit kinerja dan audit dengan tujuan tertentu, yang terdiri atas audit investigatif, audit atas penyelenggaraan sistem pengendalian intern pemerintah, dan audit atas hal-hal lain di bidang keuangan. 43

Dalam tataran internasional, The International Organization of Supreme Audit Institutions (INTOSAI), perhimpunan badan pemeriksa keuangan sedunia, telah menerbitkan sejumlah standar internasional (the international standards of supreme audit institutions/ISSAI) dan panduan (guidance/GUID) yang mesti dipedomani oleh seluruh badan pemeriksa keuangan sedunia.

Beberapa di antara regulasi internasional itu berkaitan dengan pelaksanaan pemeriksaan dengan tujuan tertentu, yakni ISSAI 100 tentang Prinsip-Prinsip Dasar Audit Sektor Publik,44 ISSAI 400 tentang Prinsip-Prinsip Pemeriksaan Kepatuhan,45 ISSAI 4000 tentang Standar Pemeriksaan Kepatuhan,46 GUID 5100 tentang Panduan Pemeriksaan atas Sistem Informasi, ${ }^{47}$ GUID 5201 tentang Pemeriksaan Lingkungan dalam Rangka Pemeriksaan Keuangan dan Kepatuhan, ${ }^{48}$ dan GUID 5270 tentang Panduan Pemeriksaan atas Pencegahan Korupsi. ${ }^{49}$

\footnotetext{
${ }^{42}$ Baharuddin Aritonang, Badan Pemeriksa Keuangan dalam Sistem Ketatanegaraan, Jakarta: Kepustakaan Populer Gramedia, 2017, h. 92-93.

${ }_{43}^{4}$ Penjelasan Pasal 50 ayat (3) PP 60/2008.

${ }^{44}$ The International Organization of Supreme Audit Institutions, ISSAI 100: Fundamental Principles of Public-Sector Auditing, https://www.intosai.org/fileadmin/downloads/documents/open access/ISSAI 100 ISSAI 400/issai 100/issai 100 en.pdf, diunduh 3 Oktober 2019

45 The International Organization of Supreme Audit Institutions, ISSAI 400: Compliance Audit Principles, https://www.intosai.org/fileadmin/downloads/documents/open_access/ISSAI_100 ISSAI 400/issai_400/issai_400_en.pdf, diunduh 3 Oktober 2019.

${ }^{46}$ The International Organization of Supreme Audit Institutions, ISSAI 4000: Compliance Audit Standard, https://www.issai.org/wpcontent/uploads/2019/08/ISSAI-4000.pdf, diunduh 3 Oktober 2019.

${ }_{47}$ The International Organization of Supreme Audit Institutions, GUID 5100: Guidance on Audit of Information Systems, https://www.issai.org/wp-content/uploads/2019/09/Guid-5100-Guidance-on-Audit-of-Information-Systems.pdf, diunduh 3 Oktober 2019.

${ }^{48}$ The International Organization of Supreme Audit Institutions, GUID 5201: Environmental Auditing in The Context of Financial and Compliance Audits, https://www.issai.org/wp-content/uploads/2019/08/Guid-5201.pdf, diunduh 3 Oktober 2019.

${ }^{49}$ The International Organization of Supreme Audit Institutions, GUID 5270: Guideline for the Audit of Corruption Prevention, https://www.issai.org/wp-content/uploads/2019/08/Guid-5270.pdf, diunduh 3 Oktober 2019.
} 
Dengan demikian, sungguh tidak beralasan jika dikatakan bahwa BPK tidak dapat melaksanakan pemeriksaan dengan tujuan tertentu. Sebab, BPK adalah lembaga pemeriksa keuangan negara agung $5^{\circ}$ (the supreme audit institution) satu-satunya yang bebas dan mandiri yang dibentuk langsung oleh konstitusi, bahkan telah dirumuskan sejak masa-masa awal terbentuknya negara.

Ketiga, para pemohon mendalilkan bahwa pasca-terbitnya Peraturan BPK Nomor 1 Tahun 2017 tentang Standar Pemeriksaan Keuangan Negara (SPKN), pengaturan serta penjelasan terkait pemeriksaan dengan tujuan tertentu telah dicabut dan dinyatakan tidak berlaku. SPKN merupakan patokan untuk melakukan pemeriksaan pengelolaan dan tanggung jawab keuangan negara.

Menurut para pemohon, tatkala SPKN yang sebelumnya diatur melalui Peraturan BPK Nomor 1 Tahun 2007 tentang SPKN (selanjutnya disebut Peraturan BPK 1/2007) diganti dengan Peraturan BPK Nomor 1 Tahun 2017 (selanjutnya disebut Peraturan BPK 1/2017), kepastian hukum untuk melaksanakan pemeriksaan dengan tujuan tertentu menjadi hilang sebab Peraturan BPK 1/2017 tidak lagi memuat standar pelaksanaan pemeriksaan dengan tujuan tertentu..$^{51}$

Dalil terakhir ini adalah kekeliruan paling fatal dari keseluruhan alasan permohonan. Para pemohon (dan, tentu saja, kuasa hukum mereka) tidak cermat dalam membaca Peraturan BPK 1/2017. Dengan terbitnya Peraturan BPK 1/2017, memang terjadi perubahan yang cukup signifikan berkenaan dengan susunan SPKN. Namun, hal itu tidak berarti bahwa pengaturan mengenai pemeriksaan dengan tujuan tertentu yang semula termaktub secara gamblang dalam susunan SPKN berdasarkan Peraturan BPK 1/2007 menjadi hilang begitu saja.

Pergantian SPKN dilakukan untuk mengakomodasi perubahan dalam standar pemeriksaan di sektor publik dan privat yang berlaku secara nasional maupun internasional, yakni the generally accepted government auditing standards (GAGAS),,52 standar profesional akuntan publik (SPAP), 53 the international standards on auditing (ISA), 54 dan ISSAI. 55

Berdasarkan perubahan-perubahan dalam standar pemeriksaan di sektor publik dan privat tersebut, perbedaan yang paling kentara antara Peraturan BPK 1/2007 dan Peraturan BPK 1/2017 ialah dalam hal standar pemeriksaan yang awalnya menggunakan pendekatan "pengaturan standar berdasarkan aturan yang lebih rinci" (rule-based standards) berubah menjadi pendekatan "pengaturan standar berdasarkan prinsip” (principle-based standards).

\footnotetext{
${ }^{50}$ Istilah "agung" ini tidaklah berlebihan sebab telah ada jejak historis-yuridis atas istilah ini. Dalam Peraturan Pemerintah Pengganti Undang-Undang Nomor 6 Tahun 1964 tentang BPK yang kemudian ditetapkan lebih lanjut dengan Undang-Undang Nomor 17 Tahun 1965, dikenal istilah "pemeriksa keuangan agung" sebagai pimpinan BPK.

${ }^{51}$ Viktor Santoso Tandiasa dkk., op. cit., h. 28.

52 GAGAS diterbitkan oleh The United States Government Accountability Office (GAO), badan pemeriksa keuangan Amerika Serikat. Lihat The United States Government Accountability Office, Government Auditing Standards: 2018 Revision, https://www.gao.gov/assets/700/693136.pdf, diunduh 3 Oktober 2019.

53 SPAP diterbitkan oleh Institut Akuntan Publik Indonesia (IAPI) atau Indonesian Institute of Certified Public Accountants (IICPA) organisasi yang berwenang untuk melaksanakan ujian profesi akuntan publik, penyusunan dan penetapan standar profesional dan etika akuntan publik, serta menyelenggarakan program pendidikan berkelanjutan, sekaligus reviu mutu akuntan publik. Lihat Institut Akuntan Publik Indonesia, Standar Profesional Akuntan Publik, https://iapi.or.id/lapi/detail/362, diunduh 3 Oktober 2019.

${ }^{54}$ ISA diterbitkan oleh The International Federation of Accountants (IFAC), organisasi internasional untuk profesi akuntansi yang berafiliasi dengan 175 asosiasi di lebih dari 130 negara dan mewakili lebih dari tiga juta akuntan, melalui The International Auditing and Assurance Standards Board (IAASB). Lihat The International Federation of Accountants, "Publications \& Resources", https://www.iaasb.org/publications-resources?publication$\underline{\text { type }=203 \& \text { source }=30 \& \text { language }=87 \& \text { keyword }=\text { Search }+ \text { Publications } \& x=31 \& y=12}$, diunduh 3 Oktober 2019

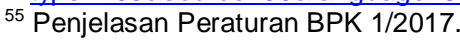


Hal ini mengakibatkan pengaturan detail mengenai pemeriksaan dengan tujuan tertentu pada SPKN yang semula diletakkan dalam satu bagian tersendiri dileburkan dan dibenamkan (embedded) ke dalam prinsip-prinsip umum dari tiga jenis pemeriksaan, yakni pemeriksaan keuangan, pemeriksaan kinerja, dan pemeriksaan dengan tujuan tertentu, sehingga menjadi lebih ringkas dan sederhana.

Dalam Peraturan BPK 1/2017, pengaturan mengenai pemeriksaan dengan tujuan tertentu antara lain terdapat pada Paragraf 3 dan 18 Lampiran I Kerangka Konseptual Pemeriksaan. Kemudian pada Paragraf 1, 5.v, 24, dan A14 Lampiran II Pernyataan Standar Pemeriksaan 100 Standar Umum. Selanjutnya pada Paragraf 8.e, 11, A14, A16, dan A23 Lampiran III Pernyataan Standar Pemeriksaan 200 Standar Pelaksanaan Pemeriksaan. Terakhir pada Paragraf 1, 16, 17, 23, A13, dan A16 Lampiran IV Pernyataan Standar Pemeriksaan 300 Standar Pelaporan Pemeriksaan.

Ketiga dalil para pemohon tersebut menunjukkan bahwa alasan permohonan (posita) para pemohon tidak jelas atau kabur (obscuur libel) dan tidak terdapat keterkaitan antara posita dan petitum yang memohon MK untuk memutuskan bahwa Pasal 4 ayat (1) UU 15/2004 dan Pasal 6 ayat (3) UU 15/2006 bertentangan dengan UUD 1945. Oleh karena itu, demi keadilan, MK haruslah memutuskan bahwa permohonan para pemohon tidak dapat diterima (niet ontvankelijk verklaard).

\section{Ketiadaan kedudukan hukum para pemohon}

Berkas Permohonan Nomor 1900/PAN.MK/VIII/2019 perihal Permohonan Pengujian Pasal 4 ayat (1) UU 15/2004 dan Pasal 6 ayat (3) UU 15/2006 terhadap UUD 1945 diajukan oleh Ahmad Redi (Pemohon I), Muhammad Ilham Hermawan (Pemohon II), dan Kexia Goutama (Pemohon III) yang diwakili oleh kuasa hukum para pemohon: Viktor Santoso Tandiasa, Yohanes Mahatma Pambudianto, Aida Mardatillah, dan Eko Ibnuhayyan.

Pemohon I adalah dosen Fakultas Hukum Universitas Tarumanagara. Menyelesaikan pendidikan sarjana di Fakultas Hukum Universitas Diponegoro (2007) dan master di Program Magister Ilmu Hukum Universitas Indonesia (2009), ia melanjutkan studi pada Program Doktor Ilmu Hukum Universitas Indonesia dan lulus dengan predikat cumlaude (2013)..$^{6}$

Pemohon I pernah bekerja di Kementerian Sekretariat Negara dengan jabatan terakhir sebagai Kepala Subbidang Sumber Daya Alam pada Deputi Bidang Perundang-undangan. ${ }^{57}$ Pada 2014 ia memutuskan untuk menjadi dosen di Fakultas Hukum Universitas Tarumanagara. $5^{8}$ Sebagai dosen, ia banyak menulis sejumlah buku, makalah, dan artikel populer di pelbagai media massa. Ia juga kerap diundang sebagai narasumber di forum-forum ilmiah dan sering dimintai pendapat dalam diskusi-diskusi interaktif di televisi.59

Pemohon II adalah dosen Fakultas Hukum Universitas Pancasila. Menyelesaikan pendidikan sarjana di Fakultas Hukum Universitas Pancasila (2000) dan master di Program Magister Ilmu

\footnotetext{
${ }^{56}$ Pemohon I tercatat sebagai peraih doktor hukum tercepat dalam sejarah Fakultas Hukum Universitas Indonesia. Detiknews, "Ahmad Redi, Peraih Doktor Hukum Tercepat dalam Sejarah FHUI", https://news.detik.com/tokoh/d-2267037/ahmad-redi-peraihdoktor-hukum-tercepat-dalam-sejarah-fhui, diunduh 16 September 2019.

${ }_{57}$ Ahmad Redi, “Tentang Redi", https://ahmadredi.com/tentang-redi, diunduh 16 September 2019.

${ }^{58}$ Facebook, "Ahmad Redi", https://www.facebook.com/ahmad.redi, diunduh 16 September 2019.

${ }^{59}$ Lihat, misalnya, diskusi Pemohon I di CNN Indonesia terkait negosiasi antara Pemerintah RI dan PT Freeport Indonesia: CNN Indonesia, "Adu Kuat Negosiasi Tambang", https://www.youtube.com/watch?v=ISkXpnKIsD8, diunduh 16 September 2019.
} 
Hukum Universitas Indonesia (2004), ia melanjutkan studi pada Program Doktor Ilmu Hukum Universitas Indonesia dan lulus pada 2015. ${ }^{60}$

Pemohon II banyak menulis karya ilmiah bertema filsafat hukum dan hermeneutika (penafsiran) konstitusi. Selain itu, ia juga kerap menjadi narasumber dalam lokakarya atau seminar di perguruan tinggi, anggota tim ahli penyusun peraturan perundang-undangan, dan pemberi keterangan ahli di persidangan. ${ }^{61}$

Pemohon III adalah mahasiswa Fakultas Hukum Universitas Tarumanagara. Tulisan-tulisannya beberapa kali disiarkan oleh media massa. ${ }^{62}$ Ia juga beberapa kali memenangi lomba debat dan legislative drafting mewakili Universitas Tarumanagara. ${ }^{63}$

Amat menarik jika merunut benang merah relasi profil di antara para pemohon. Pemohon I dan III jelas berhubungan secara subordinatif-akademis sebagai dosen dan mahasiswa di Universitas Tarumanagara. Pemohon I dan II pun ternyata memiliki hubungan koordinatifakademis: keduanya tergabung dalam struktur kepengurusan Kolegium Jurist Institute, suatu pusat studi yang fokus pada penelitian tentang kebijakan dan reformasi di bidang hukum. ${ }^{64}$

Kondisi kian menarik karena pada 7 Oktober 2019 para pemohon mengajukan perbaikan permohonan. Dalam perbaikan permohonan, para pemohon tidak hanya mengubah substansi permohonan, melainkan juga mengganti Pemohon I menjadi Ibnu Sina Chandranegara dan Pemohon II menjadi Auliya Khasanofa, sementara Pemohon III tetap. Penggantian (substitusi) pemohon merupakan hal yang tidak lazim dalam permohonan pengujian undang-undang dan menarik untuk dikaji lebih lanjut.

Pemohon I dan Pemohon II merupakan dosen pada Fakultas Hukum Universitas Muhammadiyah Jakarta dan Fakultas Hukum Universitas Muhammadiyah Tangerang. ${ }^{65}$ Keduanya bergiat pada Masyarakat Hukum Tata Negara Muhammadiyah (Mahutama), organisasi non-struktural dari Muhammadiyah, organisasi massa Islam terbesar kedua di Indonesia. ${ }^{66}$ Pemohon I juga merupakan peneliti senior Kolegium Jurist Institute. ${ }^{67}$

Pemohon I dan II (lama) dan Pemohon I dan II (baru) terjalin dalam satu benang merah relasi profil. Pemohon I dan II (lama) dan Pemohon I dan II (baru) pernah terlibat dalam satu

${ }_{61}^{60}$ Muhammad Ilham Hermawan, "Aku (CV)", https://ilhamendra.wordpress.com/aku-cv, diunduh 16 September 2019.

${ }^{61}$ Ibid.

${ }^{62}$ Lihat Kexia Goutama, "Negara Wajib Wujudkan Pelayaran yang Aman”, http://koran-sindo.com/page/news/2018-0719/1/4/Negara Wajib Wujudkan Pelayaran yang Aman, diunduh 17 September 2019 atau Kexia Goutama, "Tahun Politik Harus Menghadirkan Optimisme", http://koran-sindo.com/page/news/2019-01-09/1/4/Tahun Politik Harus Menghadirkan Optimisme, diunduh 17 September 2019.

${ }^{63}$ Lihat Universitas Tarumanagara, "Mahasiswa FH Untar Mampu Bersaing di Legislative Drafting Tingkat Nasional", http://untar.ac.id/pages/beritadetail/37811/Mahasiswa+FH+Untar+Mampu+Bersaing+di+Legislative+Drafting+Tingkat+Nasional, diunduh 17 September 2019 atau LPM Adigama, "Universitas Tarumanagara Kembali Juarai Lomba Debat MK Tingkat Regional", https://timeline.line.me/post/ dUDCYwwvY2edrZ3zK5jS1QPmzcgXxT2KEVYYa9g/1155504386803060887, diunduh 17 September 2019.

${ }^{64}$ Dalam Kolegium Jurist Institute, Pemohon I menjabat sebagai direktur eksekutif dan Pemohon II sebagai direktur kajian reform asi hukum dan kebijakan. Salah satu kuasa hukum para pemohon, Eko lbnuhayyan, menjabat sebagai sekretaris jenderal. Kolegium Jurist Institute, "Struktur Organisasi", https://www.kji.or.id, diunduh 19 September 2019.

65 Viktor Santoso Tandiasa dkk., op. cit., h. 8.

${ }^{66}$ Mahutama dideklarasikan pada 1 Maret 2019 dengan Aidul Fitriciada Azhari, anggota Komisi Yudisial RI, sebagai ketua umum dan Auliya Khasanofa sebagai sekretaris jenderal. Suara Muhammadiyah, "Hari ini Deklarasi Masyarakat Hukum Tata Negara Muhammadiyah", http://www.suaramuhammadiyah.id/2019/03/01/hari-ini-deklarasi-masyarakat-hukum-tata-negaramuhammadiyah, diunduh 20 Februari 2020.

${ }_{67}$ Ibnu Sina Chandranegara, "Defining Judicial Independence and Accountability Post Political Transition", Constitutional Review, Volume 5, Nomor 2, Desember 2019, h. 1. 
kegiatan yang sama. ${ }^{68}$ Begitupun organisasi mereka, Mahutama dan Kolegium Jurist Institute, juga pernah terlibat dalam satu kegiatan yang sama. ${ }^{69}$

Dalam Perbaikan Berkas Permohonan Nomor 1900/PAN.MK/VIII/2019 Tanggal 7 Oktober 2019, para pemohon mendalilkan tiga kerugian konstitusional atas berlakunya Pasal 4 ayat (1) UU 15/2004 dan Pasal 6 ayat (3) UU 15/2006. Pertama, tugas BPK untuk melaksanakan pemeriksaan dengan tujuan tertentu berpotensi menimbulkan penyalahgunaan kekuasaan (abuse of power). Dengan dilakukannya pemeriksaan dengan tujuan tertentu, menurut para pemohon, roda pemerintahan dapat terhambat sehingga merugikan para pemohon sebagai warga negara. $7^{0}$

Kedua, Pemohon I dan II mengalami kesulitan saat harus menjelaskan kepada publik tentang konstitusionalitas pemeriksaan dengan tujuan tertentu BPK terhadap suatu lembaga negara padahal lembaga tersebut telah memperoleh opini wajar tanpa pengecualian (WTP). ${ }^{71}$ Kesulitan saat harus menjelaskan kepada publik ini dianggap oleh Pemohon I dan II sebagai kerugian konstitusional. $7^{2}$

Pemohon I dan II menyitir Putusan MK Nomor 49/PUU-IX/2011 dan mempersamakan kedudukan hukum para pemohon pada putusan tersebut dengan kedudukan hukum Pemohon I dan II.73 Ketiga, Pemohon III mengalami kesulitan dalam memahami kedudukan pemeriksaan dengan tujuan tertentu karena ketiadaan penjelasan yang komprehensif. Hal ini dianggap Pemohon III sebagai kerugian konstitusional. ${ }^{74}$

Profil dan dalil-dalil para pemohon tersebut menunjukkan bahwa para pemohon tidak memiliki kedudukan hukum karena hak konstitusional mereka sama sekali tidak dirugikan dengan berlakunya Pasal 4 ayat (1) UU 15/2004 dan Pasal 6 ayat (3) UU 15/2006. Hal ini karena, pertama, profil para pemohon tidak berkaitan secara langsung dengan tugas BPK. Keterkaitan antara profil para pemohon dan tugas BPK ini penting untuk diungkap guna membuktikan kerugian konstitusional para pemohon atas berlakunya norma undang-undang yang hendak diuji.

Tugas BPK adalah memeriksa pengelolaan dan pertanggungjawaban keuangan negara. Keuangan negara sebagai objek pemeriksaan BPK, sebagaimana telah penulis jelaskan dalam bagian sebelum ini, didefinisikan secara limitatif dalam sembilan perkara. Pertanyaannya kemudian adalah apakah para pemohon dapat membuktikan diri mereka sebagai pihak yang pernah diperiksa BPK-khususnya dalam wujud pemeriksaan dengan tujuan tertentu-

\footnotetext{
${ }^{68}$ Harian Terbit, "PPPSRS Bentukan Penghuni Tidak Profesional Kelola Apartemen", https://www.harianterbit.com/index.php/read/104246/PPPSRS-Bentukan-Penghuni-Tidak-Profesional-Kelola-Apartemen, diunduh 20 Februari 2020.

${ }^{69}$ Suara Muhammadiyah, "Mahutama dan Jurist Institute Menyoroti Pemilu Serentak 2019", http://www.suaramuhammadiyah.id/2019/04/30/mahutama-dan-jurist-institute-menyoroti-pemilu-serentak-2019, diunduh 20 Februari 2020.

70 Viktor Santoso Tandiasa dkk., op. cit., h. 12.

${ }^{71}$ Opini wajar tanpa pengecualian, disingkat WTP, adalah opini tertinggi pemeriksa atas kewajaran informasi yang disajikan dalam laporan keuangan. Opini adalah pernyataan profesional pemeriksa mengenai kewajaran informasi keuangan yang disajikan dalam laporan keuangan yang didasarkan pada kriteria (1) kesesuaian dengan standar akuntansi pemerintahan, (2) kecukupan pengungkapan, (3) kepatuhan terhadap peraturan perundang-undangan, dan (4) efektivitas sistem pengendalian intern. Ada empat jenis opini yang dapat diberikan oleh pemeriksa, yakni (1) WTP, (2) wajar dengan pengecualian (WDP), (3) tidak wajar (TW), dan (4) tidak menyatakan pendapat (TMP). Menurut Sukrisno Agoes dan Jan Hoesada, ilmu pemeriksaan (auditing) memilih untuk menggunakan istilah "layak" atau "wajar", dan bukan "benar", didasarkan pada kerendahhatian sosial dan spiritual tanpa cemas atau peduli akan risiko degradasi rasa hormat publik terhadap profesi pemeriksa (auditor) atas penggunaan istilah "layak" atau "wajar" itu. Sukrisno Agoes dan Jan Hoesada, op. cit., h. 4.

72 Viktor Santoso Tandiasa dkk., op. cit., h. 13.

73 Ibid., h. 14-16.

${ }^{74}$ Viktor Santoso Tandiasa dkk., op. cit., h. 16.
} 
berkenaan dengan objek pemeriksaan BPK tersebut, untuk menunjukkan adanya hubungan sebab akibat (kausalitas) antara kerugian konstitusional dan berlakunya undang-undang yang dimohonkan pengujian?75

Hanya Pemohon I (lama)-lah yang barangkali dapat menjawab pertanyaan itu lantaran ia pernah menduduki jabatan di Kementerian Sekretariat Negara, entitas pemegang kekuasaan pengelolaan keuangan negara yang menjadi objek pemeriksaan (auditee) BPK. Namun, ia sama sekali tidak menyinggung soal statusnya itu dalam permohonan. Kendati Pemohon I (lama) mengungkapkan statusnya pun, ia tetap harus menunjukkan secara jelas dan rinci mengenai kapan dan dalam hal apa persinggungannya dengan pemeriksaan dengan tujuan tertentu oleh BPK itu terjadi. Tanpa penjelasan yang memadai, maka permohonan para pemohon haruslah diputuskan tidak dapat diterima (niet ontvankelijk verklaard).

Kedua, dalil para pemohon yang menyatakan bahwa tugas BPK untuk melaksanakan pemeriksaan dengan tujuan tertentu berpotensi menimbulkan penyalahgunaan kekuasaan adalah asumsi yang tidak didukung dengan bukti-bukti dan penalaran logis yang kuat. Jika asumsi ini dibenarkan, bukan tidak mungkin setiap lembaga yang mengemban tugas dan wewenang dari negara akan dapat turut dipersoalkan dengan alasan penyalahgunaan kekuasaan.

Tamsil yang diajukan para pemohon mengenai pelaksanaan pemeriksaan dengan tujuan tertentu BPK terhadap Komisi Pemberantasan Korupsi (KPK) ${ }^{76}$ tidak dapat dijadikan dasar bahwa pelaksanaan tugas tersebut adalah suatu penyalahgunaan kekuasaan. Sebab, selama BPK dapat menjelaskan tujuan, lingkup, dan metodologi pemeriksaan serta mematuhi kode etikdan semua ini wajib menurut SPKN77-maka BPK sah untuk melaksanakan pemeriksaan tersebut. Upaya para pemohon mengaitkan kasus tindak pidana korupsi KTP elektronik dan kasus suap pemeriksa BPK adalah asumsi yang tidak jelas korelasinya dengan permohonan para pemohon.

BPK tetap berwenang melaksanakan pemeriksaan dengan tujuan tertentu terhadap entitas pemegang kekuasaan pengelolaan keuangan negara kendatipun terhadap entitas tersebut sebelumnya telah dilakukan pemeriksaan. Pemeriksaan rutin BPK atas KPK yang disinggung para pemohon sebenarnya adalah pemeriksaan keuangan yang dilaksanakan untuk menilai kewajaran laporan keuangan berupa opini.

Pemeriksaan keuangan juga dikenal sebagai general audit karena "hanya" merupakan pemeriksaan secara umum yang tidak fokus pada satu transaksi keuangan atau hal-hal tertentu di bidang keuangan. Pada galibnya, BPK melakukan pendalaman lebih lanjut atas temuantemuan pemeriksaan keuangan yang signifikan melalui pemeriksaan dengan tujuan tertentubahkan meskipun pemeriksa telah menyatakan opini WTP dalam pemeriksaan keuangan itu. Upaya para pemohon mengaitkan antara maksud pelaksanaan pemeriksaan dengan tujuan

\footnotetext{
${ }^{75}$ Bisariyadi, “Membedah Doktrin Kerugian Konstitusional”, Jurnal Konstitusi, Volume 14, Nomor 1, Maret 2017 , h. 33.

${ }^{76}$ Viktor Santoso Tandiasa dkk., op. cit., h. 13.

77 Lihat Peraturan BPK 1/2017 pada Paragraf 12 Lampiran III Pernyataan Standar Pemeriksaan 200 Standar Pelaksanaan Pemeriksaan serta Paragraf 10, A8, A9, dan A10 Lampiran IV Pernyataan Standar Pemeriksaan 300 Standar Pelaporan Pemeriksaan.
} 
tertentu dan opini laporan keuangan mengesankan bahwa para pemohon tidak memahami ilmu akuntansi dan pemeriksaan (auditing). 78

Ketiga, dalil para pemohon yang mempersamakan kedudukan hukum para pemohon dengan kedudukan hukum para pemohon dalam Putusan MK Nomor 49/PUU-IX/2011 adalah tidak relevan. Jika hendak dipersamakan untuk dapat memiliki kedudukan hukum, para pemohon seharusnya berstatus sebagai pakar hukum keuangan negara, akuntan, pemeriksa (auditor), atau pihak yang secara langsung terperiksa BPK.

Penilaian MK mengenai kedudukan hukum para pemohon dalam putusan itu tidak dapat dipersamakan begitu saja oleh para pemohon. Latar belakang para pemohon selaku pengajar hukum tata negara79 dalam Putusan MK Nomor 49/PUU-IX/2011 menjadi relevan sebab norma yang diuji adalah Pasal 4 ayat (4) huruf f, g, dan h; Pasal 10; Pasal 15 ayat (2) huruf h; Pasal 26 ayat (5); Pasal 27A ayat (2) huruf c, d, dan e; Pasal 15 ayat (3), (4), (5), dan (6); Pasal 50A; Pasal 59 ayat (2); dan Pasal 87 UU 24/2003 yang memuat konstitusionalitas kelembagaan MK. Kendatipun Putusan MK Nomor 49/PUU-IX/2011 sesungguhnya merupakan salah satu putusan yang kontroversial karena MK menguji undang-undang yang mengatur eksistensinya sendiri. ${ }^{80}$

Di samping itu, jika merujuk pada Putusan MK Nomor 27/PUU-VII/2009,81 para pemohon tidak jelas berdiri demi kepentingan siapa. Apabila demi kepentingan publik, justru publiklah yang diuntungkan dengan adanya pelaksanaan pemeriksaan dengan tujuan tertentu oleh BPK. Melalui pemeriksaan dengan tujuan tertentu, BPK mengungkap sejumlah indikasi atau potensi kerugian negara akibat penyimpangan dalam pengelolaan keuangan negara. ${ }^{82}$

Jika para pemohon berdiri demi kepentingan badan hukum, pemerintah daerah, atau lembaga negara, profil para pemohon tidak menunjukkan hal itu dan bahkan tidak berkorelasi secara logis dengan unsur kerugian konstitusional yang bersifat spesifik dan aktual atau potensial akan terjadi berkenaan dengan berlakunya norma undang-undang yang hendak diuji. ${ }^{83}$ Oleh karena itu, demi keadilan, MK haruslah memutuskan bahwa permohonan para pemohon tidak dapat diterima (niet ontvankelijk verklaard).

\footnotetext{
${ }^{78}$ Lihat A.P. Edi Atmaja, "Salah Kaprah Opini Publik tentang BPK", Harian Analisa, 21 Juli 2016, h. 20, atau A.P. Edi Atmaja, "Seputar Kritik terhadap Pemeriksaan BPK", https://www.qureta.com/post/seputar-kritik-terhadap-pemeriksaan-bpk, diunduh 5 Oktober 2019.

79 Putusan MK Nomor 49/PUU-IX/2011, h. 65.

${ }^{80}$ Tanto Lailam, "Pro-Kontra Kewenangan Mahkamah Konstitusi dalam Menguji Undang-Undang yang Mengatur Eksistensinya", Jurnal Konstitusi, Volume 12, Nomor 4, Desember 2015, h. 813.

${ }^{81}$ Putusan MK Nomor 27/PUU-VII/2009 antara lain menyatakan, "Dari praktik Mahkamah (2003-2009), perorangan WNI terutama pembayar pajak (tax payer, vide Putusan Nomor 003/PUU-I/2003) berbagai asosiasi dan NGO/LSM yang concern terhadap suatu undang-undang demi kepentingan publik, badan hukum, pemerintah daerah, lembaga negara, dan lain-lain oleh Mahkamah dianggap memiliki legal standing untuk mengajukan permohonan pengujian, baik formil maupun materiil, undang-undang terhadap UUD 1945." Putusan MK Nomor 49/PUU-IX/2011, h. 65.

${ }^{82}$ Misalnya pemeriksaan dengan tujuan tertentu BPK yang mengungkap potensi kerugian negara pada PT Pertamina (Persero) sebesar Rp222,65 miliar, pemborosan keuangan pada PT Pabrik Gula Rajawali II senilai Rp 330,44 miliar, piutang usaha yang berpotensi tidak tertagih pada Perum Perumnas sebesar Rp 184,62 miliar, dan kekurangan penerimaan pada PT Angkasa Pura I (Persero) sebesar Rp 135,80 miliar. Herdaru Purnomo, "Ssst.. Ada Temuan BPK di Perumnas, Pertamina, dan BUMN Ini", https://www.cnbcindonesia.com/news/20190529113721-4-75721/ssst-ada-temuan-bpk-di-perumnas-pertamina-dan-bumn-ini, diunduh 5 Oktober 2019.

${ }^{83}$ Bisariyadi, op. cit., h. 41.
} 


\section{PENUTUP}

Berkas Permohonan Nomor 1900/PAN.MK/VIII/2019 yang teregistrasi melalui Perkara Nomor 54/PUU-XVII/2019 memuat permohonan uji materi Pasal 4 ayat (1) UU 15/2004 dan Pasal 6 ayat (3) UU 15/2006 terhadap UUD 1945 terkait tugas BPK untuk melaksanakan pemeriksaan dengan tujuan tertentu. Tulisan ini selesai ditulis pada saat perkara belum diputus dan masih berada dalam tahapan persidangan di MK.

Berdasarkan hasil analisis atas permohonan para pemohon, tulisan ini menyimpulkan bahwa terdapat dua persoalan yang mesti dipertimbangkan hakim. Pertama, para pemohon tidak memahami-bahkan keliru secara fatal dalam memahami-pemeriksaan dengan tujuan tertentu yang dilaksanakan oleh BPK sehingga permohonan menjadi tidak jelas atau kabur (obscuur libel). Hal ini disebabkan para pemohon mengabaikan disiplin ilmu akuntansi dan pemeriksaan (auditing) yang merupakan ruh dari segala norma dan pengaturan tentang pemeriksaan pengelolaan dan tanggung jawab keuangan negara oleh BPK.

Kedua, para pemohon tidak memiliki kedudukan hukum karena hak konstitusional para pemohon sama sekali tidak dirugikan dengan berlakunya Pasal 4 ayat (1) UU 15/2004 dan Pasal 6 ayat (3) UU 15/2006. Terhadap dua persoalan tersebut, tulisan ini merekomendasikan kepada MK untuk memutuskan bahwa permohonan para pemohon tidak dapat diterima (niet ontvankelijk verklaard).

\section{DAFTAR RUJUKAN}

Buku

Badan Pemeriksa Keuangan RI, Ikhtisar Hasil Pemeriksaan Semester I Tahun 2018, https://www.bpk.go.id/assets/files/ihps/2018/I/ihps i 2018 1538459607.pdf.

Badan Pemeriksa Keuangan RI, Ikhtisar Hasil Pemeriksaan Semester II Tahun 2018, https://www.bpk.go.id/assets/files/ihps/2018/II/ihps ii 2018 1559017101.pdf.

Badan Pemeriksa Keuangan RI, Laporan Hasil Pemeriksaan Kinerja atas Efektivitas Penanganan Perkara Pengujian Undang-Undang Tahun Anggaran 2016 dan Tahun Anggaran 2017 (sampai dengan Triwulan III) pada Mahkamah Konstitusi di Jakarta, Nomor 02/HP/XVI/01/2018 Tanggal 23 Januari 2018.

Baharuddin Aritonang, Badan Pemeriksa Keuangan dalam Sistem Ketatanegaraan, Jakarta: Kepustakaan Populer Gramedia, 2017.

Emerson Yuntho dkk., Panduan Eksaminasi Publik (Edisi Revisi 2011), Jakarta: Indonesia Corruption Watch, 2011.

Harun Kamil dkk., Badan Pemeriksa Keuangan dalam Proses Perubahan Undang-Undang Dasar Negara Republik Indonesia Tahun 1945, Jakarta: Sekretariat Jenderal Badan Pemeriksa Keuangan RI, 2012.

Indra Bastian, Audit Sektor Publik: Pemeriksaan Pertanggungjawaban Pemerintahan, Jakarta: Salemba Empat, 2014.

Sukrisno Agoes, Auditing: Petunjuk Praktis Pemeriksaan Akuntan oleh Akuntan Publik (Edisi 4 Buku I), Jakarta: Salemba Empat, 2012.

Sukrisno Agoes dan Jan Hoesada, Bunga Rampai Auditing (Edisi 2), Jakarta: Salemba Empat, 2012. 
Tim Penyusun Hukum Acara Mahkamah Konstitusi, Hukum Acara Mahkamah Konstitusi, Jakarta: Sekretariat Jenderal dan Kepaniteraan Mahkamah Konstitusi RI, 2010.

Makalah

A.P. Edi Atmaja, “Salah Kaprah Opini Publik tentang BPK”, Harian Analisa, 21 Juli 2016.

Ahmad Fadlil Sumadi, "Hukum Acara Mahkamah Konstitusi dalam Teori dan Praktik", Jurnal Konstitusi, Volume 8, Nomor 6, Desember 2011.

Bisariyadi, "Membedah Doktrin Kerugian Konstitusional", Jurnal Konstitusi, Volume 14, Nomor 1, Maret 2017.

Ibnu Sina Chandranegara, "Defining Judicial Independence and Accountability Post Political Transition”, Constitutional Review, Volume 5, Nomor 2, Desember 2019.

Tanto Lailam, "Pro-Kontra Kewenangan Mahkamah Konstitusi dalam Menguji Undang-Undang yang Mengatur Eksistensinya”, Jurnal Konstitusi, Volume 12, Nomor 4, Desember 2015.

\section{Laman Internet}

A.P. Edi Atmaja, "Seputar Kritik terhadap Pemeriksaan BPK", https://www.qureta.com/post/seputar-kritik-terhadap-pemeriksaan-bpk.

Ahmad Redi, “Tentang Redi”, https://ahmadredi.com/tentang-redi.

Badan Pengembangan dan Pembinaan Bahasa, Kementerian Pendidikan dan Kebudayaan RI, "KBBI Daring", https://kbbi.kemdikbud.go.id/entri/tugas.

CNN Indonesia, "Adu Kuat Negosiasi Tambang", https://www.youtube.com/watch?v=ISkXpnKlsD8.

Detiknews, "Ahmad Redi, Peraih Doktor Hukum Tercepat dalam Sejarah FHUI", https://news.detik.com/tokoh/d-2267037/ahmad-redi-peraih-doktor-hukum-tercepat-dalamsejarah-fhui.

Facebook, “Ahmad Redi”, https://www.facebook.com/ahmad.redi.

Harian Terbit, "PPPSRS Bentukan Penghuni Tidak Profesional Kelola Apartemen", https://www.harianterbit.com/index.php/read/104246/PPPSRS-Bentukan-Penghuni-TidakProfesional-Kelola-Apartemen.

Herdaru Purnomo, "Ssst.. Ada Temuan BPK di Perumnas, Pertamina, dan BUMN Ini", https://www.cnbcindonesia.com/news/20190529113721-4-75721/ssst-ada-temuan-bpk-diperumnas-pertamina-dan-bumn-ini.

Kexia Goutama, "Negara Wajib Wujudkan Pelayaran yang Aman", http://koransindo.com/page/news/2018-07-19/1/4/Negara Wajib Wujudkan Pelayaran yang Aman.

Kexia Goutama, "Tahun Politik Harus Menghadirkan Optimisme”, http://koransindo.com/page/news/2019-01-09/1/4/Tahun Politik Harus Menghadirkan Optimisme.

Kolegium Jurist Institute, "Struktur Organisasi”, https://www.kji.or.id.

LPM Adigama, "Universitas Tarumanagara Kembali Juarai Lomba Debat MK Tingkat Regional",

https://timeline.line.me/post/ dUDCYwwvY2edrZ3zK5jS1QPmzcgXxT2KEVYYa9g/115550438 6803060887.

Mahkamah Konstitusi RI, "Registrasi", https://mkri.id/index.php?page=web.Registrasi2\&menu=4.

Muhammad Ilham Hermawan, “Aku (CV)”, https://ilhamendra.wordpress.com/aku-cv. 
Suara Muhammadiyah, "Hari ini Deklarasi Masyarakat Hukum Tata Negara Muhammadiyah", http://www.suaramuhammadiyah.id/2019/03/01/hari-ini-deklarasi-masyarakat-hukum-tatanegara-muhammadiyah.

Suara Muhammadiyah, "Mahutama dan Jurist Institute Menyoroti Pemilu Serentak 2019", http://www.suaramuhammadiyah.id/2019/04/30/mahutama-dan-jurist-institute-menyorotipemilu-serentak-2019.

Sudikno Mertokusumo, "Gugatan Actio Popularis dan Batas Kewenangan Hakim", https://www.hukumonline.com/berita/baca/hol15774/gugatan-actio-popularis-dan-bataskewenangan-hakim.

Universitas Tarumanagara, "Mahasiswa FH Untar Mampu Bersaing di Legislative Drafting Tingkat Nasional”, http://untar.ac.id/pages/beritadetail/37811/Mahasiswa+FH+Untar+Mampu+Bersaing+di+Leg islative+Drafting+Tingkat+Nasional.

\section{Regulasi}

Undang-Undang Dasar Negara Republik Indonesia Tahun 1945.

Undang-Undang Nomor 17 Tahun 2003 tentang Keuangan Negara.

Undang-Undang Nomor 1 Tahun 2004 tentang Perbendaharaan Negara.

Undang-Undang Nomor 15 Tahun 2004 tentang Pemeriksaan Pengelolaan dan Tanggung Jawab Keuangan Negara.

Undang-Undang Nomor 15 Tahun 2006 tentang Badan Pemeriksa Keuangan.

Putusan Mahkamah Konstitusi Nomor 49/PUU-IX/2011.

Peraturan Badan Pemeriksa Keuangan Nomor 1 Tahun 2017 tentang Standar Pemeriksaan Keuangan Negara.

Peraturan Mahkamah Konstitusi Nomor 06/PMK/2005 tentang Pedoman Beracara dalam Perkara Pengujian Undang-Undang.

Institut Akuntan Publik Indonesia, Standar Profesional Akuntan Publik, https://iapi.or.id/Iapi/detail/362.

The International Federation of Accountants, "Publications \& Resources", https://www.iaasb.org/publications-resources?publication-

type $=203 \&$ source $=30 \&$ language $=87 \&$ keyword $=$ Search + Publications $\& x=31 \& y=12$.

The International Organization of Supreme Audit Institutions, ISSAI 10o: Fundamental Principles of Public-Sector Auditing, https://www.intosai.org/fileadmin/downloads/documents/open access/ISSAI 100 ISSAI 4 00/issai 100/issai 100 en.pdf.

The International Organization of Supreme Audit Institutions, ISSAI 40o: Compliance Audit Principles, https://www.intosai.org/fileadmin/downloads/documents/open access/ISSAI 100 ISSAI 4 00/issai $400 /$ issai 400 en.pdf.

The International Organization of Supreme Audit Institutions, ISSAI 40oo: Compliance Audit Standard, https://www.issai.org/wp-content/uploads/2019/08/ISSAI-4000.pdf.

The International Organization of Supreme Audit Institutions, GUID 510o: Guidance on Audit of Information Systems, https://www.issai.org/wp-content/uploads/2019/og/Guid-5100Guidance-on-Audit-of-Information-Systems.pdf. 
The International Organization of Supreme Audit Institutions, GUID 5201: Environmental Auditing in The Context of Financial and Compliance Audits, https://www.issai.org/wpcontent/uploads/2019/08/Guid-5201.pdf.

The International Organization of Supreme Audit Institutions, GUID 5270: Guideline for the Audit of Corruption Prevention, https://www.issai.org/wp-content/uploads/2019/o8/Guid5270.pdf.

The United States Government Accountability Office, Government Auditing Standards: 2018 Revision, https://www.gao.gov/assets/700/693136.pdf.

Dokumen Lain

Viktor Santoso Tandiasa dkk., "Berkas Permohonan Nomor 1900/PAN.MK/VIII/2019", https://mkri.id/public/filesimpp/berkas $2683 \quad 1900 \% 20-$

\%20Dr.\%20Ahmad\%20Redi,\%20S.H.,\%20M.H.,\%20dkk.pdf.

Viktor Santoso Tandiasa dkk., "Perbaikan Berkas Permohonan Nomor 1900/PAN.MK/VIII/2019”,

https://mkri.id/public/filesimpp/berkasReg 2769 Perbaikan\%20Permohonan\%2oPerkara\%2 oNomor\%2054\%20PUU\%20XVII\%202019.pdf.

\section{BIODATA}

A.P. Edi Atmaja adalah pemeriksa ahli pertama pada Badan Pemeriksa Keuangan RI. Menyelesaikan pendidikan sarjana pada Fakultas Hukum Universitas Diponegoro (2012) dan master pada Program Magister Ilmu Hukum Universitas Diponegoro (2013), ia banyak menulis di media massa tentang hukum internasional, hukum tata negara, hukum keuangan negara, dan isu-isu tentang BPK. Pada 2014 ia mengikuti pendidikan dan pelatihan Jabatan Fungsional Pemeriksa dan telah tuntas menunaikan tiga jenis pemeriksaan yang merupakan tugas BPK: pemeriksaan keuangan, pemeriksaan kinerja, dan pemeriksaan dengan tujuan tertentu. 